\title{
LUMINESCENCE CHRONOLOGY OF ALLUVIAL FAN IN NORTH BENGAL, INDIA: IMPLICATIONS TO TECTONICS AND CLIMATE
}

\author{
ATUL K. SINGH ${ }^{1}$, MANOJ K. JAISWAL ${ }^{1}$, JITENDRA K. PATTANAIK ${ }^{1,2}$ and MAHA DEV ${ }^{1}$ \\ ${ }^{1}$ Department of Earth Sciences, Indian Institute of Science Education and Research, Kolkata 741246, India \\ ${ }^{2}$ Environment and Earth Sciences, Central University of Punjab, Bathinda-151001, Punjab, India
}

Received 30 June 2015

Accepted 1 July 2016

\begin{abstract}
Alluvial fans are important geomorphic archives because of its strategic location at mountain front which can provide clues to the past climate and tectonics. In general, they provide information about optimum climate condition suitable for fan formation. We provide a detailed luminescence chronology of alluvial fan in north West Bengal, India. The regional fan surface $\left(\mathrm{T}_{4}\right)$ has been dissected by E-W trending Himalayan thrusts known as Matiali and Chalsa thrusts and have various terraces named as $T_{3}, T_{2}$ and youngest one as $T_{1}$. Luminescence ages suggest that the formation of the alluvial fan (regional surface) started before $171 \mathrm{ka}$ and continued till $72 \mathrm{ka}$ covering a time span of nearly $100 \mathrm{ky}$; suggesting of weaker monsoon at $72 \mathrm{ka}$. Matiali fault activated after $171 \mathrm{ky}$. Chalsa fault is suggested to be active during 48-41 ka. The last aggradational phase was around $6 \mathrm{ka}$ which led to the formation of $\mathrm{T}_{1 \mathrm{a}}$ terrace. The study suggests that climatic fluctuation during the period were shaping the morphology of the alluvial fan, along with tectonic activities on the two faults.
\end{abstract}

Keywords: OSL dating, SAR, North Bengal Himalayas, alluvial fan, fluvial terraces.

\section{INTRODUCTION}

The collision of the Indian and the Eurasian plates resulted in north-south contraction of the lithosphere and development of southward propagating fold and thrust belt (FTB) (Molnar and Tapponnier, 1975; Molnar, 1984; Guha et al., 2007). Himalayas are one of the few longest mountain ranges in the world, comparable with Andes, Rocky Mountains, Great Dividing Range etc. The Himalayan FTB has been divided by northward dipping major boundary thrusts; Main Central Thrust (MCT) separates the crystalline Higher Himalayas from the metamorphosed Lesser Himalayas, Main Boundary Thrust (MBT) separates the Lesser Himalayas from the sedimentary rocks of the Siwaliks and Main Frontal Thrust (MFT)

Corresponding author: M. K. Jaiswal

e-mail: mkjosl@gmail.com being the southernmost expression of FTB at mountain front separates the Siwaliks from the Quaternary deposits (Gansser, 1964, 1981). Himalayas provide a natural laboratory to the earth scientist trying to understand the balance between uplift, incision and erosion in an actively deforming orogen, resulting in topographic evolution on the $10^{5}-10^{7}$ years timescales (Lavé and Avouac, 2000; Wobus et al., 2005). In present day scenario, the convergence between the Indian and the Eurasian plate is majorly accommodated by the movement on the MFT (Lavé and Avouac, 2000; Kumar et al., 2001; Malik et al., 2003; Malik and Nakata, 2003; Lavé et al., 2005).The MFT has mappable surface expressions in piedmont zones of Uttranchal, Darjeeling, and Arunachal Pradesh Himalayas (Raiverman et al., 1990; Valdiya et al., 1992; Srivastava and John, 1999; Sarkar and Som, 2001; Mukhopadhyay and Mishra, 2004). It is a commonly accepted hypothesis that either the thrust tip is blind in most of the areas or its trace is buried by rapid accumulation of sediments (Raiverman et al., 1990; Valdiya et al., 
1992; Srivastava and John, 1999; Mukul 2000; Sarkar and Som, 2001; Mukhopadhyay and Mishra, 2004). In the Darjeeling foothill Himalayas, to the east of the Tista River, the MFT has discontinuous and nonlinear surface expressions (Nakata, 1989; Guha et al., 2007; Goswami et al., 2012).

Himalayan foreland basins are suitable to understand the role of climate and tectonics in alluvial fan sedimentation, as this region has been affected by both the factors (Nakata, 1972; Ruddiman et al., 1989; Valdiya et al., 1992, 1993; Singh et al., 2001; Goodbred, 2003; Srivastava et al., 2003; Gibling et al., 2005; Sinha et al., 2005). Singh (1996a, 1996b) suggested that the mega fans formed in the initial part of humid phases preceded by a long period of arid climate, which helped in generating sediments. Srivastava et al. (2003) attempted luminescence chronology of Yamuna Ganga mega fans with multiple aliquot additive dose method and reported its formation during 26-22 ka, but did not rule out the possibility of insufficient bleaching and hence an overestimation of the ages. Jaiswal, (2006, unpublished thesis) reassessed the dates of (Srivastava et al., 2003) using Single Aliquot Regeneration (SAR) method and suggested that the mega fan sedimentation was during the humid phase ( 14-16 ka) preceded by Last Glacial maxima (LGM), which supports the hypothesis of (Singh 1996a, 1996b). Under wet conditions rivers not only flush out the produced sediments but also incise the bedrock forming various levels of terraces and intense uplifting in tectonically active areas is reflected by large number of rock-cut terraces (Starkel, 2003). The study of quaternary deposits may provide important clues to the sedimentation style at long mountain chains spread all over the world which are similar to Himalayas. Thus the study of alluvial fans and fluvial terraces may provide information on the river dynamics on regional scale and effect of climate-tectonic interactions on the evolution of these landscapes.

A lot of work has been done in the western Himalayas to understand the mechanism shaping the morphology of the area along with the geochronology (Singh et al., 2001; Srivastava et al., 2003; Suresh et al., 2007; Kumar et al., 2007), whereas such work is less common in Darjeeling-Sikkim Himalayas (Mukul et al., 2007; Kar et al., 2014). Current study focuses on an alluvial fan in Darjeeling-Sikkim Himalayas, drained by the rivers like Neora, Kurti and Murti in the northern part of West Bengal, India (Fig. 1). A few studies have been done earlier in the region to understand the formation of this fan but they lack sufficient geochronological data. The alluvial fan east of the Tista River in the Mal - Murti interfluves area is named as the Matiali fan (Fig. 1). At mountain fronts in Himalayas, the Indian monsoon system plays an important role in regulating the sediment supply and its transportation, thus controls the evolution of the fan system. In addition to this the Matiali fan has been affected by several tectonic movements along the Chalsa and
Matiali faults. Thus, this fan provides an opportunity to explore climate-tectonics interactions.

Guha et al. (2007), based on their two radiocarbon dates, one near the Gorubathan thrust and another near the Chalsa thrust attempted to explain the evolution of fan. However, the C-14 age of 33,875 \pm 550 Ybp near the Gorubathan thrust (Guha et al., 2007) gives only a lower bound and shows that the fan formation started before that. This date have been found much lower than other radiocarbon age, reported to be $\sim 46.4$ ka by Ghosh et al., (2015) from a terrace in the distal part of the fan. However these dates were taken from proximal and distal part of the fan therefore cannot be compared. Kar et al., (2014) provided 3 optical ages from the terraces on the Neora and Kurti rivers in the distal part of the fan which are young ages (all below $11 \mathrm{ka}$ ). This shows that there is an ambiguity in terms of chronology. Goswami et al., (2013) using total station and remote sensing suggested that this fan is affected majorly by tectonics. Kar et al., (2014) discussed the evolution of the fan and linked it with the past climate neglecting any role of tectonics, in general. As the fan is located in between MBT and MFT, the development of fan is controlled by both climate and tectonics. However, which is a dominant factor, is still a controversy. The detailed chronology of various fans located along the MFT may be helpful in solving these issues. The Matiali fan is a complex geomorphic entity which has been under continuous deformation and needs detailed chronological study to frame these tectonic movements. The present work provides a detailed chronology of the area using optical dating and attempts to remove the ambiguity in geochronological data and thus, helps in understanding the geomorphic evolution of the alluvial fan with time.

\section{GEOMORPHOLOGY OF THE AREA}

The study area is an alluvial fan bound by major rivers, the Mal in the west and the Murti in the east, which originate in the Higher Himalayas. The alluvial fan is dissected by many smaller order tributaries of these major rivers, e.g. the Kurti and the Juranti which originate in the piedmont zone itself (Fig. 1c). Two East-West trending scarps, the Matiali scarp in north and the Chalsa scarp in the south considered as the splay of the MBT and the MFT respectively owe their origin to the movement on blind thrust below these scarps (Nakata 1989; Guha et al., 2007) (Fig. 1). One more scarp named as the Gorubathan scarp exist to the north of Matiali scarp but could not be studied due to lack of suitable exposure, also represents MBT (Fig. 1) (Guha et al., 2007). Nakata (1989) identified three geomorphic surfaces in the Quaternary deposits, viz., Matiali, Rangmati and Samsing in order of their time of formation, Matiali being the oldest and Samsing as the youngest. He also categorized terraces in three groups: (i) Lower River Terrace or Younger River Terrace (LRT or YRT), (ii) Middle river terraces (MRT) and 


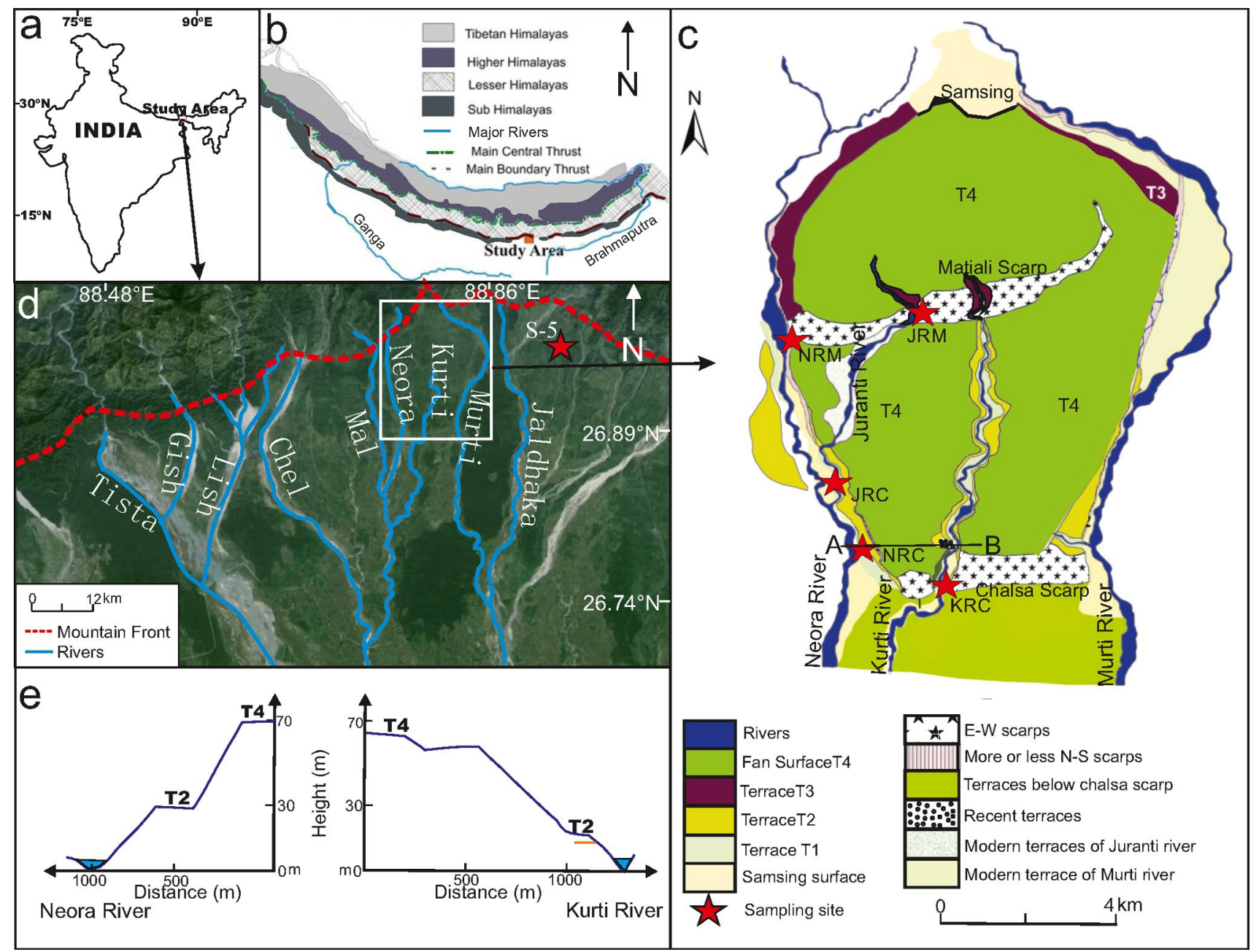

Fig. 1. (a) The study region lies in the northern part of West Bengal, India. (b) The figure shows the tectonic division of the Himalayas and the present study area. (c) The figure shows the major geomorphic features in the study area. The sampling sites are marked with red star. The northern most fault known as Gorubathan is marked by black line just below the Samsing surface. The two other E-W scarps/faults viz. Matiali and Chalsa are also shown in the figure. The NNE-SSW and nearly N-S scarps along which the Murti and Neora rivers flow respectively are also shown in the figure (after Goswami et al., 2013). (d) This is the Google earth image of the region showing the major rivers in the area. A red star shows the OSL sample location of S-5 coinciding with the location of radiocarbon date provided by Guha et al. (2007) (e) The figure shows the height of the different geomorphic features from the river bed near the Chalsa scarp along the line AB in Fig. 1c (after Goswami et al., 2013).

(iii) Higher river terrace (HRT). However, based on pedological studies, Das and Chattopadhyay (1993a, 1993b) considered Matiali and Rangamati to be a single geomorphic surface and Samsing to be the oldest surface. Similar classification was followed by later workers (Guha et al., 2007; Goswami et al., 2012, 2013; Kar et al., 2014). Goswami et al., $(2012,2013)$ classified regional highest surface of the fan as $\mathrm{T}_{4}$ and subsequent lower surfaces as $T_{3}, T_{2}$ and $T_{1}$. The regional slope of the fan is southerly $\left(2.1^{\circ}\right)$, at the head, height is $550 \mathrm{~m}$ above mean sea level (MSL) which decreases to $200 \mathrm{~m}$ above MSL at toe (Goswami et al., 2012, 2013). Goswami et al., (2013) reported that the Matiali and the Chalsa scarps are manifestation of antiforms over two north dipping blind thrusts. The regional fan surface $\mathrm{T}_{4}$ has been dissected and incised by many rivers like Neora, Murti,
Kurti and Juranti forming lower terraces. $T_{3}$ occurs as raised terrace north of the Matiali scarp on both the banks of the Murti, Kurti, Juranti and only on the east bank of the Neora river. South of the Matiali scarp, raised terraces on the banks of Neora, Kurti and Murti are designated as $T_{2}$ and $T_{1}$. Terrace $T_{2}$ has an average height of $200 \mathrm{~m}$ above MSL. $T_{1}$ is above recent flood plains and has an average height of $180 \mathrm{~m}$ above MSL. Matiali scarp is highest $(60 \mathrm{~m})$ on the eastern bank of the Neora River and its height decreases eastward and the scarp dies out on the western bank of the Murti River after taking a north-east bend (Fig. 1). Chalsa scarp is $90 \mathrm{~m}$ in the Neora-Murti interfluve area, traceable from the Chel River to Mal River and in the Murti-Jaldhaka interfluves area also. The higher surfaces show signature of deformation whereas the lower small terraces are undeformed. In addition to E- 
W trending scarps, there are transverse faults trending NNE-SSW and nearly N-S along which the present day Murti and Neora rivers flow (Goswami et al., 2012, 2013; Ghosh et al., 2015). The radial drainage pattern, north of the Matiali scarp has been modified by later tectonism (Goswami et al., 2012).

\section{LUMINESCENCE CHRONOLOGY-METHODS AND SAMPLING}

Optically stimulated Luminescence (OSL) dating provides the date of the event of last exposure of sediments to sunlight, thus giving burial ages (Huntley et al., 1985; Aitken, 1998). The method is well suited for aeolian deposits as these samples are supposedly well bleached in daylight before burial, however in case of fluvial deposits due to various factors e.g. sediment depth, attenuation of daylight in water column and turbidity of the water along with transport depth, some part of the sediments may or may not be well bleached, thus giving overestimated ages. With the application of Single Aliquot Regenerative
(SAR) protocol of OSL dating (Murray and Wintle, 2000) one can have a better insight into the bleaching of sediments and thus can provide better estimate of ages. Luminescence dating technique using SAR has been widely used in establishing the chronology of fluvial deposits in India and in particular to Himalayas (Srivastava et al., 2003; Suresh et al., 2007; Jaiswal et al., 2008, 2009; Juyal et al., 2010; Ray and Srivastava, 2010).

The samples were collected from six locations; these sites were chosen on the basis of relative stratigraphy of different terraces (Figs. 2, 3). Among these the location of the S-5 is outside of the Matiali fan near the Taljhora scarp, close to Taljhora stream (Fig. 1d) was collected to check with independent age control provided by Guha et al., (2007).Various tests were performed on S-5 for optical dating (Fig. 4). The location of sampling sites follows and is also summarised in Table $\mathbf{1 .}$

\section{Juranti River section near Matiali (JRM section)}

Sample JRM-1 was collected from the western bank of Juranti River near Matiali scarp from the $\mathrm{T}_{4}$ surface.

Table 1. Details of sampling location along with coordinates and relative stratigraphic positions.

\begin{tabular}{|c|c|c|c|c|c|}
\hline $\begin{array}{l}\text { S. } \\
\text { No. }\end{array}$ & $\begin{array}{l}\text { Sample } \\
\text { Name }\end{array}$ & $\begin{array}{c}\text { Height above mean sea level of } \\
\text { River bed }(\mathrm{m})\end{array}$ & Location & $\begin{array}{c}\text { Thickness of sand } \\
\text { bed }(m)\end{array}$ & $\begin{array}{l}\text { Height from river } \\
\text { bed }(\mathrm{m})\end{array}$ \\
\hline 1 & $\begin{array}{l}\text { JRM-1 } \\
26^{\circ} 56^{\prime} 34.1 \text { "N } \\
88^{\circ} 47^{\prime} 16.6^{\prime \prime} \mathrm{E}\end{array}$ & 287 & $\begin{array}{l}\text { Western bank of Juranti river, near Matiali } \\
\text { scarp, basement of } T_{4}\end{array}$ & 0.5 & 1.5 \\
\hline 2 & $\begin{array}{l}\text { NRM-1 } \\
26^{\circ} 56^{\prime} 14.6^{\prime \prime} \mathrm{N} \\
88^{\circ} 45^{\prime} 41.3^{\prime \prime} \mathrm{E}\end{array}$ & 251 & $\begin{array}{l}\text { Eastern bank of Neroa, near Matiali scarp, from } \\
\qquad T_{3}\end{array}$ & 0.5 & 3 \\
\hline 3 & $\begin{array}{l}\text { NRM-2 } \\
\text {-do- }\end{array}$ & - do- & $\begin{array}{c}\text { Western bank of Neroa near Matiali scarp from } \\
\text { the } T_{4}\end{array}$ & 0.3 & 1 \\
\hline 4 & $\begin{array}{l}\mathrm{S}-5 \\
26^{\circ} 57^{\prime} 51.2^{\prime \prime} \mathrm{N} \\
88^{\circ} 55^{\prime} 51.8^{\prime \prime} \mathrm{E}\end{array}$ & 358 & Uplifted scarp material near Talijhora & 0.5 & 4 \\
\hline 5 & $\begin{array}{l}\text { KRC-1 } \\
26^{\circ} 53^{\prime} 1.1^{\prime \prime} \mathrm{N} \\
88^{\circ} 47^{\prime} 32.9^{\prime \prime} \mathrm{E}\end{array}$ & 178 & $\begin{array}{l}\text { Western bank of Kurti river near Chalsa scarp, } \\
\text { from } T_{2}\end{array}$ & 0.5 & 3 \\
\hline 6 & $\begin{array}{l}\text { KRC-2 } \\
\text {-do- }\end{array}$ & -do- & -do- & 1.05 & 18 \\
\hline 7 & $\begin{array}{l}\text { KRC-3 } \\
\text {-do- }\end{array}$ & - do- & $\begin{array}{l}\text { Western bank of Kurti river near Chalsa scarp, } \\
\text { from } T_{4}\end{array}$ & 0.26 & 15 \\
\hline 8 & $\begin{array}{l}\text { KRC-4 } \\
\text {-do- }\end{array}$ & -do- & $\begin{array}{c}\text { Western bank of Kurti river near Chalsa scarp, } \\
\text { from } T_{1}\end{array}$ & 0.28 & 3.5 \\
\hline 9 & $\begin{array}{l}\text { NRC-1 } \\
26^{\circ} 53^{\prime} 37.3^{\prime \prime} \mathrm{N} \\
88^{\circ} 46^{\prime} 30.9^{\prime \prime} \mathrm{E}\end{array}$ & 188 & $\begin{array}{c}\text { Eastern bank of Neora river near Chalsa scarp } \\
\text { from } \mathrm{T}_{4}\end{array}$ & 0.6 & 12 \\
\hline 10 & $\begin{array}{l}\text { NRC-2 } \\
\text {-do- }\end{array}$ & - do- & $\begin{array}{c}\text { Eastern bank of Neora river near Chalsa scarp } \\
\text { from } T_{4} \\
\end{array}$ & 0.3 & 30 \\
\hline 11 & $\begin{array}{l}\mathrm{NRC}-3 \\
26^{\circ} 53^{\prime} 13.6^{\prime \prime} \mathrm{N} \\
88^{\circ} 46^{\prime} 22.2^{\prime \prime} \mathrm{E}\end{array}$ & 166 & $\begin{array}{l}\text { Western bank of Neora river near Chalsa scarp } \\
\text { from } T_{2}\end{array}$ & 0.3 & 3 \\
\hline 12 & $\begin{array}{l}\text { JRC-1 } \\
26^{\circ} 54^{\prime} 05.1 \text { 'N } \\
88^{\circ} 46^{\prime} 13.4 " \mathrm{E}\end{array}$ & 189 & $\begin{array}{l}\text { Near confluence of Neora and Juranti rivers } \\
\text { from } T_{4}\end{array}$ & 0.5 & 1.5 \\
\hline 13 & $\begin{array}{l}\text { JRC-2 } \\
\text {-do- }\end{array}$ & - do- & Near confluence of Neora and Juranti from $\mathrm{T}_{1 \mathrm{a}}$ & 0.3 & 2 \\
\hline
\end{tabular}




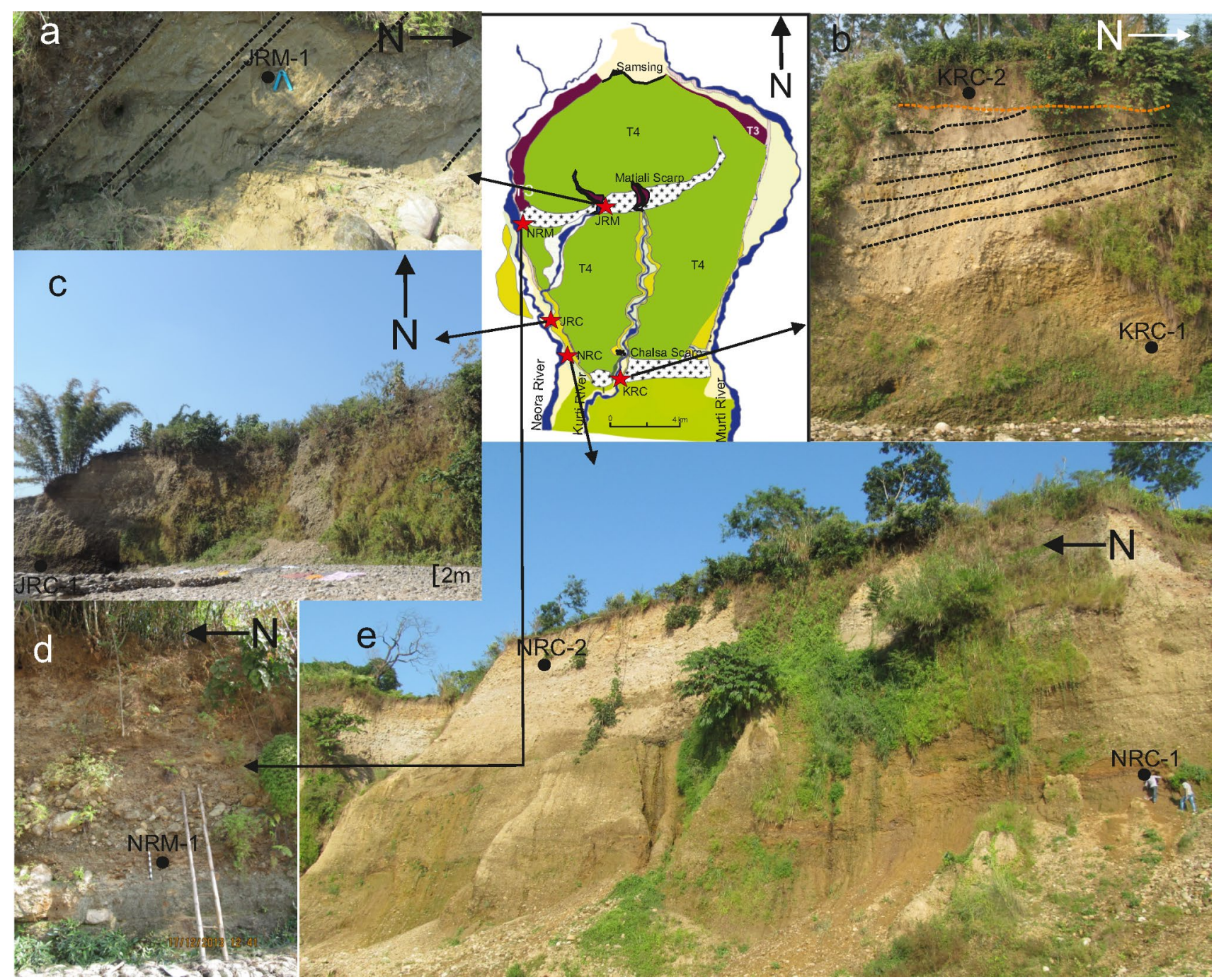

Fig. 2. The figure shows different sampling location along with the field photographs from different locations. (a) The figure shows the JRM section from which the sample JRM-1 was collected (from $T_{4}$ ) on the banks of Juranti river near Matiali scarp. The $42^{\circ}$ south dipping beds are marked by dashed black lines (Scale $=15 \mathrm{~cm}$ ). (b) This figure shows a part of KRC section from which samples KRC-1 and KRC-2 (both from $\left.T_{2}\right)$ were collected. KRC-3 was collected from $T_{4}$ and was behind this section, KRC-4 was collected from $T_{1}$ to the south of this photograph. The dashed black line shows the deformed beds and the orange line shows the unconformity in the $T_{2}$ terrace. The height of section is about $20 \mathrm{~m}$ from river bed. (c) The photograph of the JRC section from which the samples JRC-1 and JRC-2 were collected, in the foreground Juranti river could be seen. Sampling location of JRC-1 is marked and the sample JRC-2 was collected from the west facing scarp of the same section (along Neora river). A scale of $\sim 2 m$ is marked in the lower right corner of the image. (d) NRM-1 was collected from this section, it represents the T3 terrace and parallel horizontal beds of sediments could be seen. NRM-2 was collected from the opposite bank. The black and white scale in the figure is $50 \mathrm{~cm}$. (e) The photograph shows the NRC section, from which the samples NRC-1 and NRC-2 were collected (both from $T_{4}$ ). The whole section has a very gentle slope towards north. For scale two students could be seen $(\sim 170 \mathrm{~cm})$ in the right side of the photograph. The sample NRC-3 was collected from the opposite bank of the Neora river.

The beds here are dipping at $42^{\circ}$ towards south (Fig. 2a). These dipping beds are of $T_{4}$ fan surface material. This dipping of strata is due to the deformation on the Matiali thrust beneath (Goswami et al., 2012, 2013). The material is indurated arkosic pebbly sand (Fig. 2a). The exposed part of the section shows overall coarsening upward trend with intermittent sand layers, which is typical to alluvial fan sedimentation. The sand also varies in size from coarse to medium sized along with pebbles and cobbles.

\section{Neora River section near Matiali (NRM section)}

Two samples were collected from this site (i) NRM-1 was collected from the eastern bank of Neora river, from $\mathrm{T}_{3}$ terrace as defined by Goswami et al., (2013) and (ii) NRM-2 was collected from the western bank of Neora River near Matiali. NRM-2 was from a hard indurated polymictic conglomerate comprising sub-angular pebbles. Here the Neora river flows over this bed which represents the surface of the alluvial fan. $T_{3}$ terrace shows both coarsening upward as well as fining upward trends with 
well imbricated pebbles and cobbles along with few boulders (Fig. 2d). Intermittent coarse sand beds also occur, indicating changes in flow energy conditions.

\section{Kurti River section near Chalsa (KRC section)}

Four samples were collected from this site; all the samples were from the western bank of the Kurti River. KRC-1 was collected from the base of $T_{2}$, around $3 \mathrm{~m}$ from the river bed. The sand beds were dipping $17^{\circ}$ towards south and moving further south the dip of beds changes abruptly to $25^{\circ}$ within a distance of 10-12 meters (Fig. 2b). KRC-2 was collected from the top of $\mathrm{T}_{2}$ at a height of about 18 meters from the river bed and the sand beds were horizontal. KRC-4 was collected from the $\mathrm{T}_{1}$ surface, at a height of $3.5 \mathrm{~m}$ from the river bed. KRC-3 was collected from the $T_{4}$ surface. The sand beds of $T_{4}$ are highly oxidised and have reddish brown colour while sand beds of $T_{2}$ are grey coloured. All the samples are coarse to medium grained (Fig. 2b).

\section{Neora River section near Chalsa (NRC section)}

Three samples were collected from this site. NRC-1 and NRC-2 were from the eastern bank and NRC-3 was from the western bank of the Neora river near the Chalsa scarp. NRC-1 and NRC-2 were at a height of about $12 \mathrm{~m}$ and $30 \mathrm{~m}$ from the river bed respectively. The beds were showing a gentle slope towards north and the sand was oxidised having reddish brown colour, both of these samples were from the $\mathrm{T}_{4}$ surface (Fig. 2e). NRC-3 was collected from the $T_{2}$ terrace on the western bank of the Neora river.

\section{Juranti River section near confluence of Neora and Juranti Rivers (JRC section)}

JRC-1 was collected from a section near the confluence of Neora and Juranti rivers, from the sediments of $\mathrm{T}_{4}$. The section was south facing, the course of Juranti river is more or less N-S and when it reaches near Chalsa scarp it starts turning westward and finally meets with Neora river within the alluvial fan (Fig. 2c). JRC-2 was collected from a terrace designated as $\mathrm{T}_{1 \mathrm{a}}$. It is the youngest terrace and is an additional modern terrace of Neora river. A litholog of the studied area and the relative stratigraphic location of the samples collected can be seen in Fig. 3.

Samples for OSL dating were collected in galvanized iron (GI) pipes to avoid any accidental exposure to daylight, a routine method of collecting sediment sample for OSL dating. Summary of the section studied has been given in Table 1. All the samples were processed in sub-

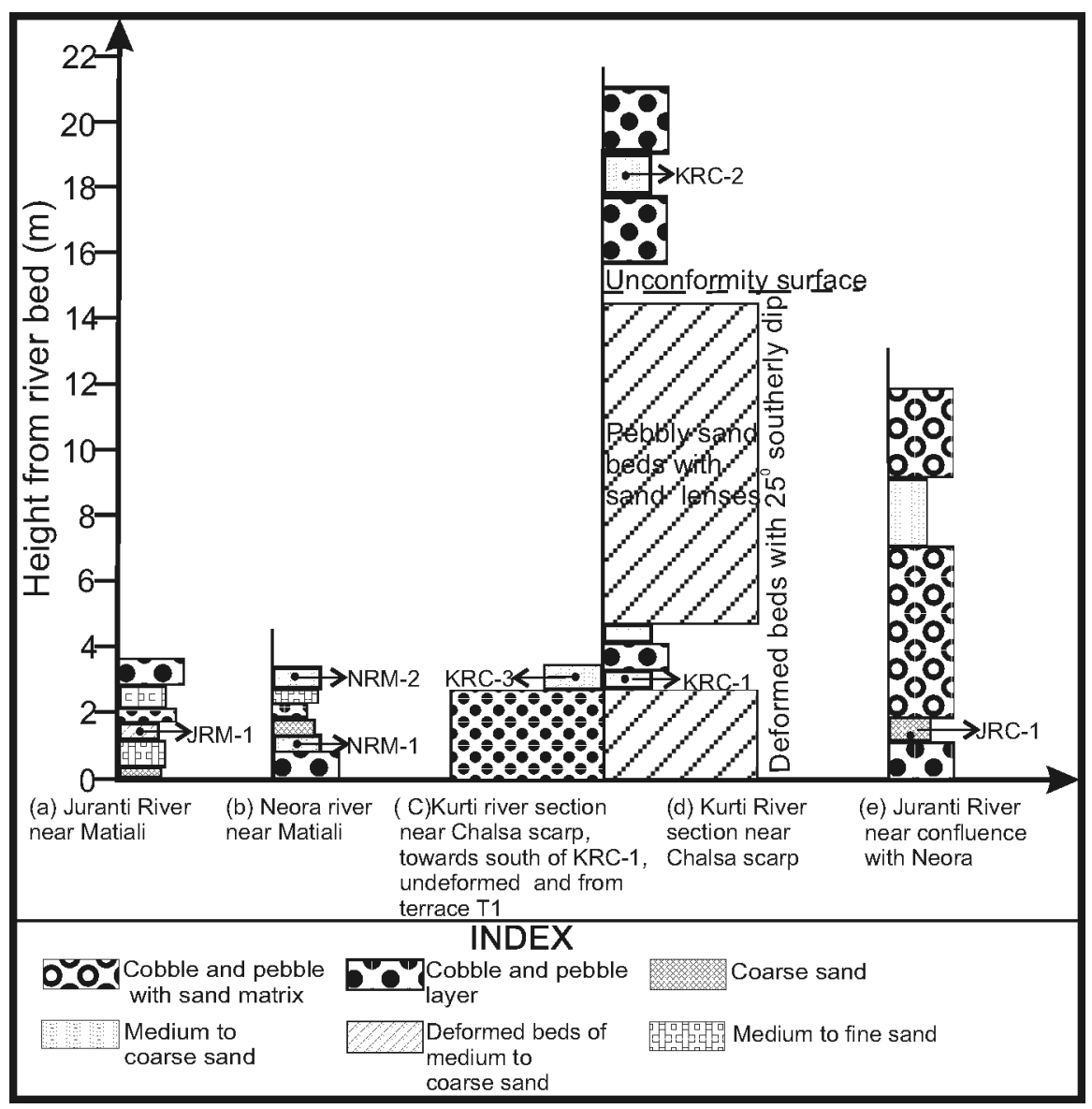

Fig. 3. Log showing stratigraphic position of different sections from which the samples were collected. 
dued red light conditions under dark room environment. The sediments were treated 3-4 times with $1 \mathrm{~N} \mathrm{HCl}$ and $30 \% \mathrm{H}_{2} \mathrm{O}_{2}$ to remove the carbonates and organic materials respectively. The sediments were then sieved to obtain size fraction of $90-150 \mu \mathrm{m}$. This was followed by heavy liquid density separation using Sodium polytungstate $\left(\right.$ density $\left.=2.58 \mathrm{gm} / \mathrm{cm}^{3}\right)$ to separate quartz and feldspar. Obtained quartz grain were etched with $40 \% \mathrm{HF}$ for 80 minutes to remove alpha dose affected layer and feldspar contaminations present (if any after heavy liquid separation) followed by $12 \mathrm{~N} \mathrm{HCl}$ treatment to dissolve the fluorides formed during etching. All samples were checked for feldspar contamination using Infrared stimulated luminescence (IRSL) at room temperature.

The quartz grains obtained from sediments in Himalayas suffers from low and changing sensitivity, in general. This limits the possibility of reducing the aliquot size, although small aliquot increases the chance of detecting poorly bleached samples (Wallinga, 2002). Even with low photon counts and bigger aliquots, this quartz can be used meaningfully in age calculation (Jaiswal et al., 2008; Ray and Srivastava, 2010). Aliquots of $\sim 8 \mathrm{~mm}$ were prepared on stainless steel disks of $10 \mathrm{~mm}$ diameter, the grains were mounted on the disks using Silko-Spray silicone oil. Standard SAR protocol (Murray and Wintle, 2000) was applied to obtain equivalent dose for each sample. The optical luminescence measurements were made on Lexsygsmart TL-OSL reader (Freiberg Instruments, Germany) at luminescence dating laboratory in IISER Kolkata. The instrument beta dose rate was calibrated using calibration quartz supplied from the Risoe National Laboratory, Denmark Technical University, Denmark. The instrument is equipped with blue light emitting LEDs $(\lambda=458 \mathrm{~nm})$, the detection window con- sists of a combination of optical filters Hoya U340 and Delta BP 365/50 EX mounted on a solid state photomultiplier tube (PMT) designed to have very low background counts. $\mathrm{A}^{90} \mathrm{Sr} /{ }^{90} \mathrm{Y}$ beta source is used for irradiation. The pre heat plateau test was performed on S-5 by heating aliquots to different temperatures for different time periods and it was found that the $260^{\circ} \mathrm{C}$ for 20 seconds is the most suitable temperature and time for measuring natural signal and regeneration doses. Back ground subtracted integral of 0.1 second of initial part of shine down (rapid bleaching part) curve was used for equivalent doses calculations (Fig. 4a). The dose recovery test was performed on the laboratory bleached aliquots of sample S-5. A laboratory beta dose of 151.4 Gy was administered to a set of 5 aliquots and treating them natural, recovered using SAR to evaluate equivalent dose (Fig. 4c). The results have shown excellent recovery using SAR and were recovered within $10 \%$ of the given laboratory doses. Some samples had very low signals due to which the recuperation varied from $0-10 \%$. The disks showing best fit of data and recycling ratio within $0.9-1.1$ were chosen for equivalent dose estimation. Since all the ages were well above $1 \mathrm{ka}$, average ED was preferred for age calculation (Jain et al., 2004). The growth curve was plotted for the JRM-1 to check the suitability of the sample for OSL (Fig. 4b). The histograms showing dose distribution were plotted for sample JRM-1 (Fig. 4d). ICPMS was used to measure the concentration of radioactive elements ( $\mathrm{U}$, Th and $\mathrm{K}$ ). Estimation of moisture content is a very difficult task, especially in areas like North Bengal where there is a lot of variation in rainfall during different seasons therefore; estimation of $15 \pm 5 \%$ in samples close to river bed and $10 \pm 5 \%$ in areas at greater height from the river bed has been made.

Table 2. OSL age table of analyzed samples showing various parameters for age calculation.

\begin{tabular}{|c|c|c|c|c|c|c|c|c|c|c|}
\hline S.No. & $\begin{array}{l}\text { Sample } \\
\text { Name }\end{array}$ & Terrace & $\begin{array}{c}\mathrm{U} \\
\text { (ppm) }\end{array}$ & $\begin{array}{c}\text { Th } \\
\text { (ppm) }\end{array}$ & $\begin{array}{c}K \\
(\%) \\
\end{array}$ & $\begin{array}{c}\text { Moisture } \\
(\%)\end{array}$ & $\begin{array}{l}\text { ED } \\
\text { (Gy) }\end{array}$ & $\begin{array}{l}\text { Dose Rate } \\
\text { (Gy/ka) }\end{array}$ & $\begin{array}{l}\text { Age } \\
\text { (ka) }\end{array}$ & No. of discs \\
\hline 1 & JRM-1 & $\mathrm{T}_{4}$ & $2.30 \pm 0.01$ & $19.61 \pm 0.08$ & $2.28 \pm 0.02$ & $15 \pm 5$ & $590.6 \pm 55.3$ & $3.5 \pm 0.2$ & $171 \pm 18$ & 15 \\
\hline 2 & NRM-1 & $\mathrm{T}_{3}$ & $2.81 \pm 0.02$ & $13.53 \pm 0.67$ & $2.59 \pm 0.02$ & $10 \pm 5$ & $217.3 \pm 57.2$ & $3.6 \pm 0.2$ & $59.7 \pm 16$ & 10 \\
\hline 3 & NRM-2 & $\mathrm{T}_{4}$ & $2.41 \pm 0.06$ & $16.89 \pm 0.57$ & $2.43 \pm 0.02$ & $10 \pm 5$ & $306.7 \pm 26.7$ & $3.6 \pm 0.2$ & $84.6 \pm 8.6$ & 7 \\
\hline$\overline{4}$ & S-5 & & $3.14 \pm 0.03$ & $18.40 \pm 0.65$ & $1.27 \pm 0.01$ & $15 \pm 5$ & $75.6 \pm 18.9$ & $2.7 \pm 0.1$ & $27.8 \pm 7$ & 26 \\
\hline 5 & KRC-1 & $\mathrm{T}_{2}$ & $4.71 \pm 0.12$ & $12.02 \pm 0.31$ & $1.74 \pm 0.01$ & $10 \pm 5$ & $158 \pm 36.8$ & $3.2 \pm 0.2$ & $47.7 \pm 10.7$ & 13 \\
\hline 6 & KRC-2 & $\mathrm{T}_{2}$ & $3.32 \pm 0.03$ & $23.71 \pm 0.56$ & $2.36 \pm 0.03$ & $10 \pm 5$ & $172.7 \pm 41$ & $4.2 \pm 0.2$ & $41.4 \pm 10$ & 18 \\
\hline 7 & KRC-3 & $\mathrm{T}_{4}$ & $2.09 \pm 0.10$ & $12.58 \pm 0.06$ & $1.47 \pm 0.01$ & $10 \pm 5$ & $199.4 \pm 4.6$ & $2.5 \pm 0.1$ & $80.8 \pm 4.7$ & 18 \\
\hline 8 & KRC-4 & $\mathrm{T}_{1}$ & $2.31 \pm 0.01$ & $13.07 \pm 0.10$ & $1.75 \pm 0.01$ & $10 \pm 5$ & $78.1 \pm 23.2$ & $2.8 \pm 0.2$ & $28.6 \pm 8.5$ & 15 \\
\hline 9 & NRC-1 & $\mathrm{T}_{4}$ & $2.26 \pm 0.06$ & $10.64 \pm 0.13$ & $1.51 \pm 0.08$ & $15 \pm 5$ & $209 \pm 44.5$ & $2.3 \pm 0.1$ & $89.1 \pm 17.3$ & 11 \\
\hline 10 & NRC-2 & $\mathrm{T}_{4}$ & $2.94 \pm 0.12$ & $15.81 \pm 0.16$ & $1.79 \pm 0.02$ & $10 \pm 5$ & $226.3 \pm 60.9$ & $3.1 \pm 0.2$ & $72.6 \pm 19.9$ & 18 \\
\hline 11 & NRC-3 & $\mathrm{T}_{2}$ & $3.17 \pm 0.02$ & $15.98 \pm 0.03$ & $2.41 \pm 0.01$ & $10 \pm 5$ & $211.6 \pm 68.1$ & $3.7 \pm 0.2$ & $59.4 \pm 18.1$ & 13 \\
\hline 12 & JRC-1 & $\mathrm{T}_{4}$ & $2.88 \pm 0.02$ & $15.97 \pm 0.09$ & $2.28 \pm 0.29$ & $10 \pm 5$ & $369.4 \pm 91.9$ & $3.6 \pm 0.3$ & $99.03 \pm 25.3$ & 11 \\
\hline 13 & JRC-2 & $\mathrm{T}_{1 \mathrm{a}}$ & $2.90 \pm 0.04$ & $14.75 \pm 0.28$ & $1.81 \pm 0.12$ & $10 \pm 5$ & $17.9 \pm 3.8$ & $3 \pm 0.2$ & $5.9 \pm 1.3$ & 12 \\
\hline
\end{tabular}



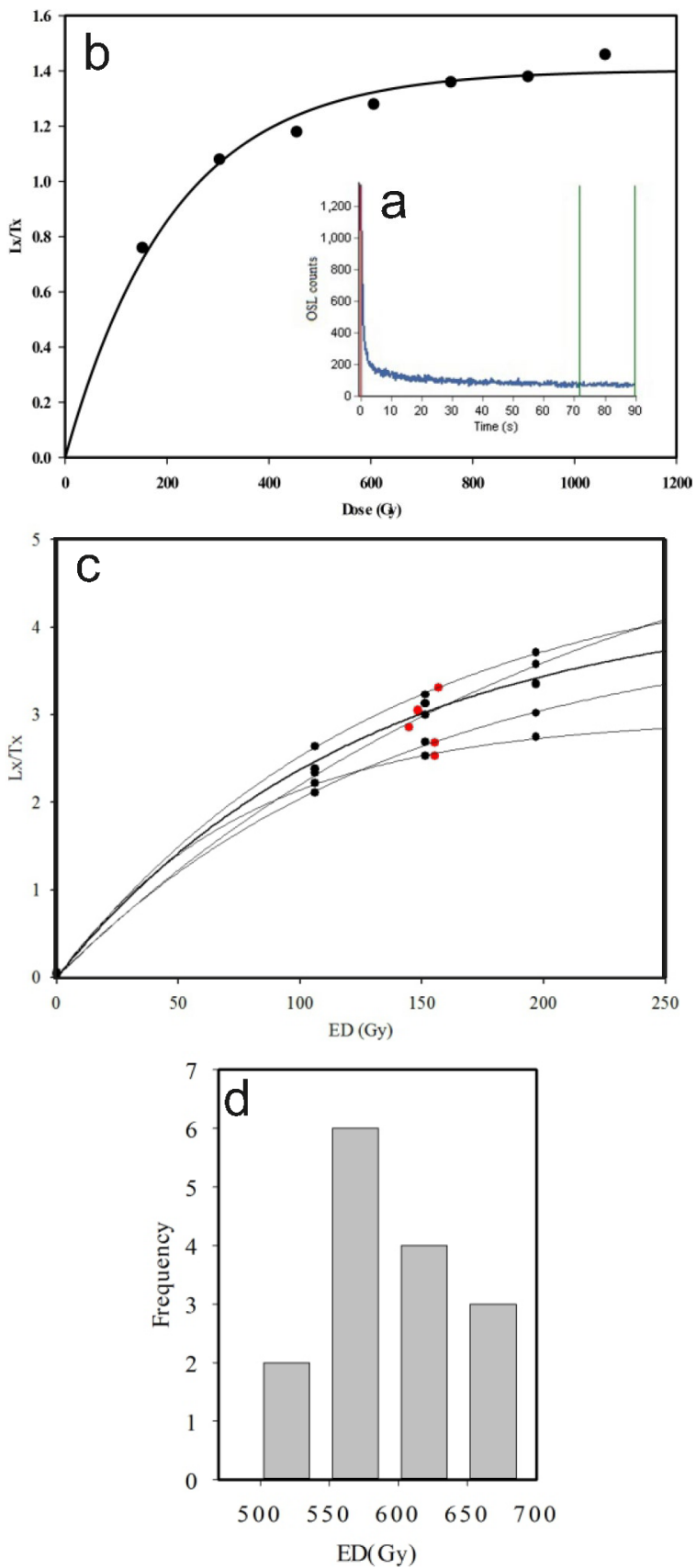

Fig. 4. (a) The BLSL shine down curve for the quartz from the JRM-1 sample. (b) The laboratory generated dose growth for the sample JRM-1. (c) The dose recovery test was performed on the S-5, laboratory dose of $151.4 \mathrm{~Gy}$ was administered and it was recovered, the red dots represent the recovered doses. It was found that all the five aliquots showed very good recovery with less than $10 \%$ of deviation from the given lab dose. (d) Histogram showing the dose distribution for the sample JRM-1.

\section{RESULTS}

OSL ages obtained from the sediments of alluvial fan and river terraces constrain the age of different depositional and incision phases. The results of OSL dates have been summarized in Table 2. The quartz obtained from the sample JRM-1, near Matiali scarp from the $\mathrm{T}_{4}$ surface, has the oldest depositional age of $171 \pm 18 \mathrm{ka}$. Further west of this location from NRM section, sample NRM-1 was collected from the terrace $T_{3}$ on the eastern bank of Neora river. It gave a depositional age of $59.7 \pm 16 \mathrm{ka}$. Sample NRM-2, from the western bank of Neora river $\left(\mathrm{T}_{4}\right)$ has a depositional age of $84.6 \pm 8.6 \mathrm{ka}$.

In KRC section on the banks of Kurti river, KRC-1 from the base of $\mathrm{T}_{2}$ terrace has a depositional age of $47.7 \pm 10.7 \mathrm{ka}$; KRC-2 from the top of this terrace has an age of $41.4 \pm 10 \mathrm{ka}$, bracketing the event of sedimentation of terrace $\mathrm{T}_{2}$. At the same location, KRC-3 has depositional age of $80.8 \pm 4.7 \mathrm{ka}$, representing the material from the alluvial fan ( $\mathrm{T}_{4}$ surface). $\mathrm{KRC}-4$, located at the southern margin of Chalsa fault, shows horizontal bedding is from the $T_{1}$ terrace and has depositional age of $28.6 \pm 8.5 \mathrm{ka}$. These beds are unaffected from the deformational events which modified the $\mathrm{T}_{2}$ terrace. NRC-1, NRC-2, and NRC-3 were collected from the NRC section. NRC-1 from the $\mathrm{T}_{4}$ surface has depositional age of $89.1 \pm 17.3 \mathrm{ka}, \mathrm{NRC}-2$ lies stratigraphically above NRC1 and gives an age of $72.6 \pm 19.9 \mathrm{ka}$. NRC-3 from the $\mathrm{T}_{2}$ terrace on the western bank of the river is $59.4 \pm 18.1 \mathrm{ka}$ old. JRC-1 collected from the JRC section near the confluence of Neora and Juranti Rivers, is the material from the $T_{4}$ and has OSL age of $99.03 \pm 25.3 \mathrm{ka}$. JRC-2 from the youngest terrace has deposition age of $5.9 \pm 1.3 \mathrm{ka}$. The OSL age of quartz obtained from the S-5 sample from the adjacent fan located further east of the Matiali and Chalsa scarps near Taljhora is $27.8 \pm 7 \mathrm{ka}$ and is in close match with C-14 age of 27,210 $\pm 240 \mathrm{Ybp}$ provided by Guha et al., (2007).

\section{DISCUSSION}

Guha et al., (2007) suggested that the oldest deposits in the region date $33,875 \pm 550 \mathrm{Ybp}$. Goswami et al., (2013); Kar et al., (2014) took this date as a bench mark and restricted the formation of the alluvial fan to this time period. However the oldest sample dated by OSL in our study gives an age of $171 \pm 18 \mathrm{ka}$, suggesting that the formation of this alluvial fan started much before than $33,875 \pm 550$ years. 
The JRM-1 from the section along the bank of the Juranti river gives a depositional age of 171 ka suggesting that the formation of the fan started before $171 \mathrm{ka}$. This formation was accompanied with a strong fluvial activity as boulders of several meters (2-3 $\mathrm{m}$ on an average) diameter and a few up to $7-8 \mathrm{~m}$ were found in the proximal part of the fan suggesting strong monsoon. The sediments in the proximal part of the fan are disorganized; lack any stratification, suggesting mass-flow deposits. The Neora river section just below the Matiali scarp from the western bank is polymictic conglomerate with angular pebbles having age of $84.6 \pm 5 \mathrm{ka}$ (NRM-2). There is a large gap of ages after $171 \mathrm{ka}$. This could be due to the tectonic movement on the Matiali thrust the sediments near the Juranti section (JRM-1 dated $171 \mathrm{Ka}$ ) have been pushed up and are exposed for sampling, while the samples collected from the Neora river section (NRM-2 dated $84.6 \mathrm{ka}$ ) near Matiali (to the south of the scarp) are not affected much by this tectonic movement as shown by horizontal beds. However, sediments between these dates may be present but not accessible. Also, there is a possibility that alluvial fan deposits are not continuous deposit at one place but spread over the whole fan area, which could be one of the reasons for gap.

The samples collected from the $T_{4}$ in the distal part of the fan near the Chala scarp give ages of $99 \mathrm{ka}$ (JRC-1), $89 \mathrm{ka}$ (NRC-1), $81 \mathrm{ka}$ (KRC-3) and $72 \mathrm{ka}$ (NRC-2) showing that the deposition of the fan continued during this time and the Matiali surface and the Rangmati surface (to the south of Matiali) are the facies variation of the alluvial fan and are not different surfaces as defined by Nakata (1989). The deposition on the fan continued till $72 \mathrm{ka}$ or a little beyond as suggested by the date of the sample NRC2. The parallel stratified beds of cobble, pebble and sand are seen in the distal part of the fan suggesting sheetflood deposits. The monsoon weakened around $72 \mathrm{ka}$ limiting the supply of sediments from the Himalayas to the foreland basin, also supported by the work of Rahman et al., (2009). Thus the sediment supply to the basin stopped. Since Kurti and Juranti Rivers originated in the alluvial fan, it is possible that they are synchronous with the fan formation and started incision after the fan formation and have exposed the fan sediments to its present level. OSL ages, thus suggest that alluvial fan formation started before $171 \mathrm{ka}$ and continued till $72 \mathrm{ka}$ at least. After that due to reduced sediment/water ratio, the river system incised the fan. After the deglaciation phase during $63 \mathrm{ka}$ (Ray and Srivastava, 2010), the river got enhanced sediment supply due to increased sediment/water ratio. This helped to make fill terraces in the valley (Pazzaglia, 2013).

The undeformed thick sand beds with coarse sand below the $\mathrm{T}_{3}$ terrace near the Matiali scarp is dated $59.7 \pm 16$ ka (NRM-1). Benn and Owen, (1998) reported enhanced summer monsoon during the last interstadial (58-24 ka) in the Himalaya. The formation of this terrace could be attributed to the initial phase of enhanced mon- soon from a transition of arid phase to humid phase. This terrace shows no signature of deformation to the north of Matiali suggesting that the formation of this terrace post dated the reactivation on the Matiali scarp. In the north of Matiali, it has an average height of $35 \mathrm{~m}$ above the river bed; to the south of Matiali it has an average height of $40 \mathrm{~m}$ above the Neora river bed (Goswami et al., 2013). Goswami et al., $(2012,2013)$ designated the term $\mathrm{T}_{3}$ to the terrace to the north of Matiali and $\mathrm{T}_{2}$ to the terrace to the south of Matiali, similar classification of HRT and MRT by Nakata, (1989) and Guha et al., (2007) is not well explained. In our study we took two samples, one from the $T_{3}$ terrace to the north of Matiali which gave an age of $59.7 \pm 16 \mathrm{ka}$ (NRM-1) and another sample to the south of Matiali near Chalsa from $\mathrm{T}_{2}$ which gave an age of $59.4 \pm 18.1$ (NRC-3) ka. Thus we deduce that the time of formation of this terrace is around $59 \mathrm{ka}$. The sediment/water ratio was high during the beginning of monsoon as there was lot of weathered product (produced during glaciation period) available for transportation so there was an aggradational phase which led to the formation of $T_{3}$ and $T_{2}$ terraces along the banks of the Neora River.

The Kurti and Juranti Rivers originate within the piedmont zone near the Matiali scarp; these are small rivers and did not respond in the similar manner as the Neora and Murti rivers to climate or tectonic changes, which have their origin in the Higher Himalayas. The Kurti and Juranti rivers probably developed as a product of gully erosion and later modified in a channel as the tectonic activity and monsoonal discharge increased along the Matiali fault. From satellite image, it is clear that Juranti river has changed its course and turned west to meet the Neora River due to the activity along the Chalsa fault (Fig. 1c). A sample at height of $3 \mathrm{~m}$ from the Kurti river bed near Chalsa gave an age of $47.7 \pm 10.7 \mathrm{ka}$ (KRC-1); these beds are deformed and dip towards south. The dip is not constant, as we move north beds tend to become horizontal, pointing that this tilting is because of tectonic activity on the Chalsa fault. In the same section at a height of about $18 \mathrm{~m}$ sediments are dated to be $41.4 \pm 10 \mathrm{ka}$ (KRC-2). These beds are not deformed and lie unconformably over the lower deformed beds. Thus we can infer that the movement on the Chalsa scarp started somewhere around $48 \mathrm{ka}$ and stopped by $41 \mathrm{ka}$. This movement helped in aggradation of the system and formation of terrace. Gully erosion along the $T_{2}$ terrace exposed the $T_{4}$ surface in contact with $T_{2}$ terrace. A sample from this surface gave an age of $80.8 \pm 4.7 \mathrm{ka}$ (KRC-3), this is indicative of a fill terrace, i.e. $\mathrm{T}_{2}$ formed adjacent to $\mathrm{T}_{4}$.

The sample dated from $\mathrm{T}_{1}$ terrace along the Kurti River gives an age of $28.6 \pm 8.5 \mathrm{ka}$ (KRC-4), this terrace shows no signature of deformation suggesting that these terraces are manifestation of climatic changes. Youngest terrace along the Neora river near its confluence with Juranti river is named as $\mathrm{T}_{1 \mathrm{a}}$ gives an age of $5.9 \pm 1.3 \mathrm{ka}$ (JRC-2) showing that the last phase of aggradation expe- 
rienced by the fan was around $6 \mathrm{ka}$ and after that the rivers have been continuously incising their valleys.

\section{CONCLUSION}

The following conclusion could be drawn from the study:

1) The formation of the alluvial fan started before $171 \mathrm{ka}$ and continued till $72 \mathrm{ka}$ covering a time span of nearly $100 \mathrm{ky}$.

2) The luminescence dates suggest weakening of monsoon around $72 \mathrm{ka}$ which reduced the sediment supply and thus the sedimentation on the fan stopped.

3) The fan has been deformed by later tectonism along Matiali and Chalsa faults. There is no direct evidence to bracket the activation in Matiali fault however; deformed section at Juranti suggests it to be younger than $171 \mathrm{ka}$.

4) OSL dates suggest activations in the Chalsa fault during 48-41 ka.

5) There have been several phase of aggradations which led to formation of the various level of terraces from the regional surface $\mathrm{T}_{4}$, (i) first phase was around $59 \mathrm{ka}$ which led to the formation of $\mathrm{T}_{3}$ surface, (ii) second aggradational phase was around 48 ka which led to the formation of the $\mathrm{T}_{2}$ terrace, (iii) third aggradational phase was observed around $28 \mathrm{ka}$ which led to the formation of $\mathrm{T}_{1}$ terrace and (iv) the last aggradational phase was around $6 \mathrm{ka}$ which led to the formation of $\mathrm{T}_{1 \mathrm{a}}$ terrace. This suggests that climatic fluctuation during the period shaped the morphology of the alluvial fan and this was also modified by tectonic activities along the two faults.

6) The OSL age of quartz from sample S-5 (27.8 \pm 7 ka) obtained from adjacent fan located east of the Matiali fan near Taljhora scarp is in close match with C-14 age $(27,210 \pm 240 \mathrm{Ybp})$ provided by Guha et al., (2007). Similarly Ghosh et al., (2015) shows that the terraces on the Neora river are $\sim 50$ ka in the distal part of the fan are comparable within error to OSL dates of $57 \pm 18.6 \mathrm{ka}$ (Table 2). It shows that the OSL dates are in good correlation with independent studies and well suited for further detailed study in this and adjacent regions of the north Bengal parts of Himalayas.

\section{ACKNOWLEDGMENTS}

We acknowledge the Director, IISER-Kolkata for providing financial support to establish Luminescence Dating laboratory at IISER-Kolkata to make this work possible. We also acknowledge Dr. Chandreyee Chakraborty from Department of Geology in Calcutta University for her help and guidance in the field work and discussions in preparing the manuscript. We also thank both the reviewers for their critical comments to improve the manuscript to present form.

\section{REFERENCES}

Aitken MJ, 1998. An Introduction to Optical Dating. Academic Press, London, 267p.

Benn DI and Owen LA, 1998. The role of the Indian summer monsoon and the mid latitude westerlies in Himalayan glaciations: review and speculative discussion. Journal of the Geological Society 155: 353-363, DOI 10.1144/gsjgs.155.2.0353.

Das A and Chattopadhyay GS, 1993a. Use of soil in building up the quaternary stratigraphy of North Bengal. Records Geological Survey of India 121(2-8): 87-91.

Das A and Chattopadhyay GS, 1993b. Neotectonics in the Tista, Jaldhaka and Torsa Interfluve belt of North Bengal. Records Geological Survey of India 121(2-8): 101-109.

Gansser A, 1981.The geodynamic history of Himalaya. In: Gupta HK and Delany FM (Eds.), Zagros-Hindukush-Himalaya: Geodynamic Evolution 3. American Geophysics Union, Geodynamic Series, Washington, pp. 111-121.

Gansser A, 1964. Geology of the Himalayas, Wiley-Interscience, New York.

Ghosh R, Bera S, Sarkar A, Puruya DK, Yao Y, Li C, 2015. A 50 ka record of monsoonal variability in the Darjeeling foothill region, eastern Himalayas. Quaternary Science Reviews 114: 100-115, DOI 10.1016/j.quascirev.2015.02.002.

Gibling MR, Tandon SK, Sinha R and Jain M, 2005. Discontinuity bounded alluvial sequences of the southern Gangetic plains, India: aggradation and degradation in response to monsoonal strength. Journal of Sedimentary Research 75: 373-389, DOI 10.2110/jsr.2005.029.

Goodbred SL, 2003. Response of the Ganges dispersal system to climate change: a source-to-sink view since the last interstade. Sedimentary Geology 162: 83-104, DOI 10.1016/S00370738(03)00217-3.

Goswami C, Mukhopadhyay D and Poddar BC, 2013. Geomorphology in relation to tectonics: A case study from the eastern Himalayan foothills of West Bengal, India. Quaternary International 298: 8092, DOI 10.1016/j.quaint.2012.12.020.

Goswami C, Mukhopadhyay D and Poddar BC, 2012. Tectonic control on the drainage system in a piedmont region in tectonically active eastern Himalayas. Frontiers of Earth Science 6(1): 29-38, DOI 10.1007/s11707-012-0297-z.

Guha D, Bardhan S, Basir SR, De AK and Sarkar A, 2007. Imprints of Himalayan thrust tectonics on the quaternary piedmont sediments of the NeoraeJaldhaka valley, DarjeelingeSikkim sub-Himalayas, India. Journal of Asian Earth Sciences 30: 464-473, DOI 10.1016/j.jseaes.2006.11.010.

Huntley DJ, Godfrey-Smith DI and Thewalt MLW, 1985. Optical dating of sediments. Nature 313: 105-107, DOI 10.1038/313105a0.

Jain M, Murray AS and Jensen LB, 2004. Optically stimulated luminescence dating: how significant is incomplete light exposure in fluvial environments? Quaternaire 15: 143-153.

Jaiswal MK, 2006. Optically stimulated luminescence dating of fluvial sediments: Applications and implications to paleoseismology and Paleoclimatology. Unpublished thesis MS University of Baroda, Vadodara, India.

Jaiswal MK, Srivastava P, Tripathi JK and Islam R, 2008. Feasibility of the SAR technique on Quartz sand of terraces of NW Himalaya: a case study from Devprayag. Geochronometria 31: 45-52, DOI 10.2478/v10003-008-0015-8.

Jaiswal MK, Bhat MI, Bali BS, Ahmad S and Chen YG, 2009. Luminescence characteristics of Quartz and Feldspar from tectonically uplifted terraces in Kashmir Basin, Jammu and Kashmir, India. Radiation Measurements, 44: 523-528, DOI 10.1016/j.radmeas.2009.04.008.

Juyal N, Sundriyal YP, Rana N, Chaudhary S and Singhvi AK, 2010. Late Quaternary fluvial aggradation and in the incision in the monsoon dominated Alaknanda valley, Central Himalaya, Uttarakhand, India. Journal of Quaternary Science 26: 1293-1304, DOI 10.1002/jqs. 1413.

Kar R, Chakraborty T, Chakraborty C, Ghosh P, Tyagi AK and Singhvi AK, 2014. Morpho-sedimentary characteristics of the quaternary 
Matiali fan and associated river terraces Jalpaiguri, India: Implications for climatic controls. Geomorphology 227: 137-152. DOI 10.1016/j.geomorph.2014.05.014.

Kumar R, Suresh N, Sangode SJ and Kumaravel V, 2007. Evolution of the Quaternary alluvial fan system in the Himalayan foreland basin: implications for tectonic and climatic decoupling. Quaternary International 159: 6-20, DOI 10.1016/j.quaint.2006.08.010.

Kumar S, Wesnousky SG, Rockwell TK, Ragona D, Thakur VC and Seitz GG, 2001. Earthquake recurrence and rupture dynamics of Himalayan Frontal Thrust, India. Science 294: 2328-2331, DOI $10.1126 /$ science. 1066195 .

Lavé J and Avouac JP, 2000. Active folding of fluvial terraces across the Siwaliks Hills, Himalaya of central Nepal. Journal of Geophysical Research 105: 5735-5770, DOI 10.1029/1999JB900292.

Lavé J, Yule D, Sapkota S, Basant K, Madden C, Attal M and Pandey R, 2005. Evidence for a great medieval earthquake (approximate to 1100 AD) in the Central Himalayas, Nepal. Science 307: 13021305, DOI 10.1126/science.1104804.

Malik JN and Nakata T, 2003. Active faults and related Late Quaternary deformation along the northwestern Himalayan Frontal Zone, India. Annals of Geophysics 46: 917-936.

Malik JN, Nakata T, Philip J, Virdi NS, 2003. Preliminary observations from a trench near Chandigarh, NW Himalaya and their bearing on active faulting. Current Science 85: 1793-1799.

Molnar P and Tapponnier P, 1975. Cenozoic tectonics of Asia - effects of a continental collision. Science 189: 419-426, DOI 10.1126/science.189.4201.419.

Molnar P, 1984. Structure and tectonics of the Himalaya: Constraints and implications of geophysical data. Annual Review of Earth and Planetary Sciences 12: 489-518, DOI 10.1146/annurev.ea.12.050184.002421.

Mukhopadhyay DK and Mishra P, 2004. The main frontal thrust (MFT), North western Himalayas: thrust trajectory and Hanging wall fold geometry from balanced cross sections. Journal of Geological Society of India 64: 739-746.

Mukul M, 2000. The geometry and kinematics of the Main Boundary Thrust and related Neotectonics in the Darjiling Himalayan foldand-thrust belt, West Bengal, India. Journal of Structural Geology 22: 1261-1283, DOI 10.1016/S0191-8141(00)00032-8.

Mukul M, Jaiswal M and Singhvi AK, 2007. Timing of recent out of sequence active deformation in the frontal Himalayan wedge: Insights from the Darjiling subHimalaya, India. Geology 35: 9991002, DOI 10.1130/G23869A.1.

Murray AS and Wintle AG, 2000. Luminescence dating of quartz using an improved single aliquot regenerative-dose protocol. Radiation Measurements 32: 57-73, DOI 10.1016/S1350-4487(99)00253-X.

Nakata T, 1989. Active Faults of the Himalaya of India and Nepal, vol. 232. Geological Society of America Special Paper, pp. 243-264.

Nataka T, 1972. Geomorphic history and Crustal Movements of the Foothills of the Himalayas, Tohoku University Science reports, $7^{\text {th }}$ Ser. (Geography) 22, pp. 39-177.

Pazzaglia FJ, 2013. Fluvial terraces. In: Shroder, J. (Editor in Chief), Wohl, E. (Ed.),Treatise on Geomorphology. Academic Press, San Diego, CA, vol. 9, Fluvial Geomorphology, pp. 379-412.

Raiverman V, Ganju JL, Ram J, Misra VN, 1990. Geological map of Himalayan foothills between Ravi and Yamuna rivers. Oil and
Natural Gas Commission, Dehradun, India.

Ray Y and Srivastava P, 2010. Widespread aggradation in the mountainous catchment of the Alaknanda-Ganga River System: timescales and implications to Hinterland foreland relationships. Quaternary Science Reviews 29: 2238-2260, DOI 10.1016/j.quascirev.2010.05.023.

Rahman W, Singh SK, Sinha R and Tandon SK, 2009. Climate control on erosion distribution over the Himalaya during the past $\sim 100 \mathrm{ka}$. Geology 37: 559-562, DOI 10.1130/G25425A.1.

Ruddiman WF, Prell WL and Raymo ME, 1989. Late Cenozoic uplift in southern Asia and the American West: Rationale for general circulation modeling experiments. Journal of Geophysical Research 94: 18379-18391, DOI 10.1029/JD094iD15p18379.

Sarkar SS and Som SK, 2001. A $30 \mathrm{~km}$ long thrust on Papumpare district of Arunachal Pradesh - probable homolog of main frontal thrust of North Western Himalaya. Indian Journal of Geology 73(2): 139-144.

Singh AK, Parkash B, Mohindra R, Thomas JV and Singhvi AK, 2001. Quaternary alluvial fan sedimentation in the Dehradun valley piggyback basin, NW Himalaya: tectonic and paleoclimatic implications. Basin Research 13: 449-471.

Singh IB, 1996a. Late Quaternary sedimentation of Ganga plain foreland basin. Proceeding Symposium NW Himalaya and foredeep. Geological Survey of India Special Publication 21: 161-172.

Singh IB, 1996b. Geological evolution of Ganga Plain-an overview. The Palaeontological Society of India 41: 99-137.

Sinha R, Tandon SK, Gibling MR, Bhattacharjee PS and Dasgupta AS, 2005. Late Quaternary geology and alluvial stratigraphy of the Ganga basin. Himalayan Geology 26: 223-240.

Srivastava DC and John G, 1999. Deformation in the Himalayan frontal fault zone: evidence from small scale structures in Mohand-Khara area, NW Himalaya. In: Jain, A.K., Manickavasagam, R.M. (Eds.), Geodynamics of the NW Himalaya, 6. Memoir of Gondwana Research Group, pp. 273-284.

Srivastava P, Singh IB, Sharma M and Singhvi AK, 2003. Luminescence chronometry and Late Quaternary geomorphic history of the Ganga Plain, India. Palaeogeography, Palaeoclimatology, Palaeoecology 197: 15-41, DOI 10.1016/S0031-0182(03)00384-5.

Starkel L, 2003. Climatically controlled terraces in uplifting mountain areas. Quaternary Science Reviews 22: 2189-2198, DOI 10.1016/S0277-3791(03)00148-3.

Suresh N, Bagati TN, Kumar R and Thakur VC, 2007. Evolution of Quaternary alluvial fans and terraces in the interamontane Pinjaur Dun, Sub-Himalaya, NW India: interaction between tectonics and climate change. Sedimentology 54: 809-833, DOI 10.1111/j.13653091.2007.00861.x.

Valdiya KS, 1993. Uplift and geomorphic rejuvenation of the Himalaya in the Quaternary period. Current Science 64: 873-885.

Valdiya KS, Joshi DD, Sharma PK, Dey P, 1992. Active Himalayan frontal fault, Main boundary thrust and Ramgarh thrust in southern Kumaun. Journal of Geological Society of India 40: 509-528.

Wallinga J, 2002. Optically stimulated luminescence dating of fluvial deposits: a review. Boreas 31: 303-322.

Wobus C, Heimsath A, Whipple K, Hodges K, 2005. Active out-of sequence thrust faulting in the central Nepalese Himalaya. Nature 434: 1008-1011, DOI 10.1038/nature03499. 